\title{
Interstate Wars and Terrorism: the Effect of External Enemies on Domestic and Transnational Terrorism
}

\author{
Yongjae Lee
}

Current research about terrorism does not pay much attention to the relationship between terrorist incidents and interstate wars. This research project examines how interstate wars influenced terrorist incidents from 1970 to 2007 through an empirical study at the monadic level. This project attempts to explain that how interstate wars reduce domestic and transnational terrorist activities through three theoretical explanations, such as the diversionary theory of war, realism, and controlling freedom. In terms of the diversionary theory of war, because external threats like a war divert citizens' discontent, terrorist incidents decrease in the war period. According to realism theory in the study of international relations, because trade that could increase other countries' relative interests decreases in wartime, terrorists have less opportunities to obtain resources. Since a government limits public liberty in order to protect national security during war, terrorists confront higher risks and lose an incentive to conduct terrorist attacks. The empirical analysis demonstrates that interstate wars decreased the numbers of domestic and transnational terrorist incidents. However, less freedom during wartime had a critical impact on increasing domestic and international terrorist incidents.

Key Words: Terrorism, War, the Diversion Effect, Trade, and Freedom

* Yongjae Lee is working as a research fellow in the Center for International Studies and a lecturer at Inha University. He obtained a Ph.D. degree in Global Affairs at Rutgers, The State University of New Jersey at Newark. His research fields are international security, international political economy, and public diplomacy. The email address is liyongzai80@gmail.com

The Korean Journal of International Studies Vol.19, No.1 (April 2021), 73-104 https://doi.org/10.14731/kjis.2021.04.19.1.73

(C) 2021 The Korean Journal of International Studies 


\section{INTRODUCTION 1}

Since the Vietnam War, many countries have suffered from severe terrorist incidents that posed a threat to national security. Many states have tried to prevent terrorist incidents because terrorist incidents destroy normal life. This research attempts to examine the relationship between interstate war and terrorism. Current research on terrorism has paid too little attention to the relationship between war and terrorism. The research question is how do interstate wars influence terrorist attacks?. This research project focuses on interstate wars as an independent variable because interstate wars are one of the most significant events to influence international relations and domestic affairs. In political science, few scholars have focused on the impact of external military conflicts on terrorism. Many scholars have tried to analyze domestic and economic effects on terrorism. Furthermore, a few scholars conducted dyadic level research and found that wars between rivals increase transnational terrorism (Chenoweth 2009; Conrad 2011, 540-541; Findley, Piazza, and Young 2012, 241-243; Sick 2003, $86-87)$.

This research project conducts empirical analyses at a monadic level and argues that the number of domestic and transnational terrorist incidents decreased during wartime. This research project tries to explain why the number of terrorist incidents decreased in wartime by applying three theoretical backgrounds, such as the diversionary theory of war, realism, and limitation of freedom. According to the diversionary theory of war, a country conducts warfare against another country in order to divert its citizens' dissatisfaction and concern (Coser, 1956). Not many countries start warfare to reduce terrorism incidents, but it is possible that interstate wars reduce domestic terrorism by diverting internal dissatisfaction. Based on realism theory in international relations, a country is reluctant to trade goods with a foreign country because it can increase the relative gains of the foreign country (Grieco 1990, 28-29; Huntington, 1993; Waltz, 1979). This tendency is more evident in a war period (Barbieri and Levy 1999, 464). Because decrease in trade during war increases the cost of transferring illegal products (drugs, weapons, and money) that support terrorist activities, terrorist activities are limited in a wartime ( $\mathrm{Li}$ and Schaub 2004, 234-235; Matthew and Shambaugh 1998, 169-170). On the other hand, public liberty may have an important effect on terrorism. As strengthened national security during wartime

1 The original manuscript has been presented at the annual meeting of Florida Political Science Association in March 2013 and the winter conference of Korean International Studies Association in December 2019. 
may limit public liberty, such as freedom of speech and behavior. Terrorists who rely on media that spread fear of terrorist activities lose the incentive to conduct terrorist activities and bear a greater cost for terrorist activities under controlled freedom during a national crisis. However, empirical results report that lower civil liberty during a war period increases domestic and transnational terrorist incidents.

\section{LITERATURE REVIEW}

Research that analyzes the relationship between interstate wars and terrorism at a monadic level is scarce. Current research focus on transnational terrorism between rival states, the association between interstate military conflicts and transnational terrorism, and effects of regime type on international terrorist attacks at a dyadic level.

Three works have examined how a rival relationship leads to terrorist attacks against an enemy state (Byman et al 2001; Conrad 2011; Findley, Piazza, and Young 2012). Cost-effectiveness, a strategic advantage, a bigger bargaining leverage, and domestic political interest lead a state conduct transnational terrorist attacks against its rival state (Findley, Piazza, and Young 2012, 236-238). A series of statistical analyses that Findley, Piazza, and Young conducted verified that interstate rivalries increase transnational terrorist incidents (Findley, Piazza, and Young 2012, 242). Conrad also argued for a similar function of terrorist attack against a rival state. Although the rival relationship involves a higher possibility of militarized disputes, rival countries avoid real military disputes most of the time (Goerta and Diehl 1993, 166-167). Conrad argues that "when the probability of war is unusually high between two states, those states are more likely to sponsor terrorist attacks against each other as an alternative to risking full-scale war. States involved in more conflictual interstate relationships experience more terrorist attacks than states that are not involved in such relationships" (Conrad 2011, 530). A state-sponsored terrorism is an alternative to war because a full-scale war is too costly and risky. State-sponsored terrorism is very attractive for a country that has a rival state because of plausible deniability and disproportionate effectiveness. For example, during the Iran-Iraq War, the Iranian government supported maritime terrorist attacks against Iraqi commercial ships on the Gulf by using small gunboats in order to retaliate against Iraqi airstrike against Iranian shipping (Sick 2003, 86-87). Empirical results that Conrad conducted proved that rival countries suffer from terrorist attacks twice 
as much as non-rival states (Conrad 2011). They also support insurgencies in its rival counterpart (Byman et al 2001; Conrad 2011). A degree of tension between two countries influences the number of an insurrection. Higher tension between rival countries is more likely to increase the number of rebellions than a lower tension relationship. Because it can destroy an economy and overthrow a government of a counterpart country at low costs, supporting uprisings in the counterpart country is an additional means of warfare (Byman et al 2001, 23-34).

In terms of methodology, previous research criticized that the monadic model cannot analyze relationships between terrorism and international conflicts accurately (Chenoweth 2009). Power asymmetry between powerful and weak countries leads the weak country to use terrorism as a tool of retaliation. That is, when the weak country fights against the strong country, it uses terrorism as an alternative attack but statistical analyses did not support this argument (Chenoweth 2009).

Some literature found a negative relationship between interstate military disputes and transnational terrorism (Li and Schaub 2004, 244, 247; Li 2005, 287). Interstate military conflict involvement decreases the number of terrorist incidents because external military conflicts increase the costs of terrorist activities by creating more strict domestic security inspection (Li 2005, 287).

Finally, regime type influences a correlation between interstate conflict and international terrorism. Regime type is an essential variable to superpowers' sponsorship for international terrorism. The Soviet Union and non-democratic countries are more likely to use international terrorist attacks as a strategic tool. Especially, when democratic countries defeat non-democratic countries, non-democratic countries conduct terrorist activities for retaliation. The Soviet Union and non-democratic countries used terrorism to retaliate the U.S. crisis intervention. Furthermore, he found that when the U.S. or the Soviet Union face a foreign policy crisis, terrorist incidents increase (O'brien 1996).

Previous research did not analyze how wars influence terrorist indents at the monadic level and ignored effects of external military conflicts on domestic terrorist incidents. These have an obvious limitation in exploring the general impact of wars on domestic terrorism in a non-rivalry relationship. 


\section{THEORY AND HYPOTHESIS}

\section{THE DIVERSIONARY THEORY OF WAR}

One of the theoretical backgrounds of this research is the diversionary theory of war. Coser's The Function of Social Conflict introduced the diversionary theory of war that argued states that outside conflicts increase internal cohesion by uniting the in-group (Coser 1956). Political leaders realize that constituencies become more cohesive when a country engages in external battles. Political leaders generate a short warfare against the other country in order to divert citizens' attention away from domestic problems, such as economic difficulty and cement their political fortunes through the 'rally around the flag' effect (Levy 1989). Internal ethnic, religious, and ideological conflicts increase motivations for diversionary actions. Ethnic, religious, and ideological diversities lead political leaders to use diversionary tactic as a real political option in many countries (Tir and Jasinski 2008, 647-648).

Although internal instability causes a diversionary attempt, previous literature did not focus on the relationship between terrorism and the diversionary theory. A few attempts have been made to showe how to apply the diversionary theory in terrorism research. Domestic terrorist incidents lead democratic leaders to have a greater incentive of a diversionary war (Foster 2017, 1371). Transnational terrorist groups target democratic countries that need a diversion effect in order to recruit members at less costs because collateral damages that violent and indiscriminate counterterrorism causes to innocent civilians help them recruit new members easily (Klein 2015, 1-2). The number of terrorist incidents increase near election time (Newman 2013, 8). European countries suffered from more domestic terrorist attacks close to elections with lower permissiveness (Aksoy 2010, 901). War on terrorism can be applied to unify a majority and solve social problems by demonizing a minority as a possible threat to conduct terrorist attacks (Kanat 2012, 507). For example, Uyghur terrorist activities gave the Chinese government an opportunity to unite Han majority (Jai 2016, 15-18). "Chinese authorities might systematically use their control of the media to stoke fear of terrorism (or the nationalist sentiments it tends to provoke) as a diversionary tactic" (Volpe 2010, 3). Multiple simultaneous attacks in an urban area can generate an effect to divert security forces and prevent them from conducting quick reactions against a primary terrorist attack (Chen, Wu, and Wu 2009, 90).

The starting point of terrorism is dissatisfaction with various social problems, such as political, ethnic, and religious discrimination. Terrorism is a violent tool to express what they want to achieve (Choo 1995; Kydd and Walter 2006, 52). In 
the real world, the diversionary theory of war cannot explain relations between terrorism and interstate wars fully (DeRouen 2000, 321), but it can explain that interstate wars reduce domestic terrorism by diverting domestic dissatisfaction in some degree.

For example, from the 1950s through the 1980s, the Argentinian junta confronted political oppositions including leftist armed groups' attacks. The Argentinian government had also tried to suppress left-wing insurgencies by supporting right-wing armed groups' attacks, such as assassinations, bombing, and torture. Especially, during the dirty war (1975-1983), the Argentine force broke down insurgent movements and protests in a systematic manner. Numerous captives were tortured and killed in secret detention centers. According to human rights organizations' argument, at least 30,000 civilians had disappeared during the dirty war (Robben 2012, 306-307). Guerrilla groups had also assassinated more than five hundred members in security and armed forces between 1960 and 1989 (Díaz Bessone, 1996).

Graph 1: Average Number of Domestic Terrorist Incidents in Argentina

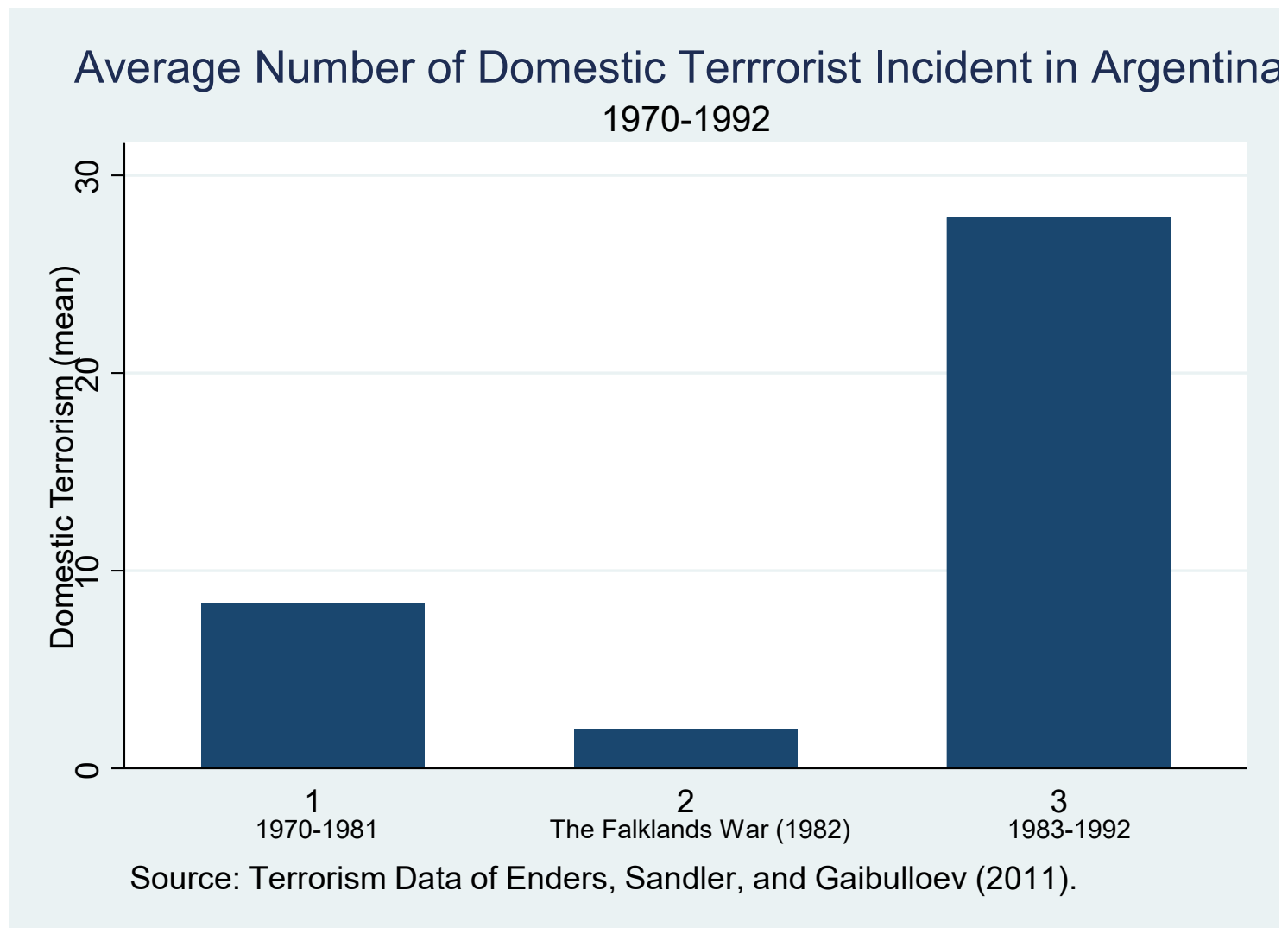


Furthermore, at that time, the collapse of the Argentine economy fueled labor unrest: extreme high inflation and unemployment rate caused daily labor protests and strikes (Suarez-Orozco 1991, 480). As Falklands War broke out in 1982, the chaos settled down for a moment. However, as the Alfonsín government failed to achieve reconciliation between the Argentine military and the insurgent groups, disputes rose again after the war (Robben 2012, 308-309). The variation of average numbers of terrorist incidents in Argentina demonstrates the diversion effect of Falklands War. Graph 1 shows the average number of domestic terrorist incidents from 1970 to 1992 in Argentina. The terrorism rate was 8.33 before Falklands War, while it decreased to 2 during the war. After the war, Argentina suffered from 27.9 terrorist incidents per year. The first hypothesis is below.

H1: A country is likely to suffer from fewerdomestic terrorist incidents during a war period than a non-war period.

\section{REALISM}

Realism assumes that a state is the main actor in an anarchical international society and engages in a struggle for power for its security. Relative power is crucial to national security (Caporaso 1993, 461; Heginbotham and Samuels 1998, 173). According to realism, a state is reluctant to conduct trade that generates bigger benefits to one state than the other state in order to avoid changes in the balance of power (Barbieri and Levy 1999, 463; Heginbotham and Samuels 1998, 174-175). The state is less likely to engage in economic exchanges with countries that show imminent military threats because dependence on goods from trade partners in war could threaten its national security (Barbieri and Levy 1999, 463; Grieco 1990, 28-29; Heginbotham and Samuels 1998, 172, 175; Huntington 1993; Waltz 1979). Moreover, "realism thus seems correct in arguing that high dependence may lead to conflict, as states use war to ensure access to vital goods” (Copeland 1996, 6). If trade dependence is lower, the possibility of war will be lower (Copeland 1996, 25). On the other hand, the hegemony stability assumption of realists has a dual position on free trade. A powerful country like a hegemon can formulate and maintain a stable economic exchange structure in order to obtain complementary goals of power, wealth and security (Kindleberger 1973; Kunkel 1998, 3-4). On the contrary, if the hegemon declines or cannot gain more benefits from a free economic exchange order, it will debilitate the free economic exchange order and move to protectionism (Kunkel 1998, 2-4; Strange 1987, 560).

A globalized economy and technological development have increased the amount of trade and foreign investment rapidly. Li and Schaub argued that trade, 
investment, and distribution networks became a primary route to support transnational terrorism.

As globalization increases, the cost of illegal activity declines relative to the cost of legal activity, and the overall level of terrorism increases. This decreased risk results from the expansion of trade, financial, and production investment networks in the global economy ( $\mathrm{Li}$ and Schaub 2004, 234). Obviously, a $2 \%$ chance of discovery is much too low to seriously prevent determined terrorist organizations from smuggling weapons of mass destruction across international borders or from conducting profitable illegal trade to finance terrorist operations ( $\mathrm{Li}$ and Schaub 2004, 235).

Especially, trade enables transnational terrorist groups to transfer workforce and equipment for terrorism between countries more easily (Matthew and Shambaugh 1998, 169-170). Moreover, the trade of contrabands, such as drugs, weapons, and diamonds increases terrorist incidents because these illegal goods are primary resources of purchasing terrorism equipment, recruiting more cadres, bribing officials, and establishing networks of communications and safe houses (Matthew and Shambaugh 1998, 169-170; Ndumbe and Cole 2005, 52; Piazza 2011, 298). Based on realism, interstate military conflicts reduce international economic cooperation, such as trade and foreign investment (Barbieri and Levy 1999, 464). It means that it is hard to support and conduct transnational terrorist incidents during wartime because transnational terrorist groups can find fewer routes to transfers terrorism funds, workforce, and facilities to foreign countries during war. In short, these war countries suffer from fewer transnational terrorist incidents than non-war countries. The second hypothesis is below.

H2: A country that undergoes an interstate war is less likely to suffer from transnational terrorist incidents.

\section{RESTRICTION OF DOMESTIC FREEDOM}

$\mathrm{Li}$ found a negative relation between terrorism and international conflicts; military conflict involvement decreases the number of terrorist incidents in the country. Because during wartime, a government strengthens domestic security by controlling citizens, costs of terrorist activities increase (Li 2005, 287). Graph 2 reports how different civil liberty is in war and peace times. During a peace period, the average civil liberty score was 4.64, while it was 3.95 during war. Sample countries were $17.47 \%$ more liberal in a non-wartime than in a war period. Because government officials consider a threat to national security more severely than it actually is, the protection of civil liberties may become less of a priority in a crisis (Whitehead and Aden 2001, 1085). Because a new urgent policy 
to reduce the threat is not well designed, freedom of citizens is limited during wartime (Tushnet 2003, 274). For example, during World War I, "congress enacted the Espionage Act of 1917. Although the act dealt primarily with espionage and sabotage, several provisions had serious consequences for the freedom of speech" (Stone 2003, 223). After the Japanese attacked Pearl Harbor, a phobia of possible Japanese espionage and sabotage was prevalent in the U.S. President Roosevelt signed Executive Order 9066 that allowed the Army to exclude people in military areas. Because of Executive Order 9066, 120,000 Japanese in California, Washington, Oregon, and Arizona had to leave their homes and stayed at detention camps (Stone 2003, 228-229).

Graph 2: Civil Freedom in War and Peace Periods

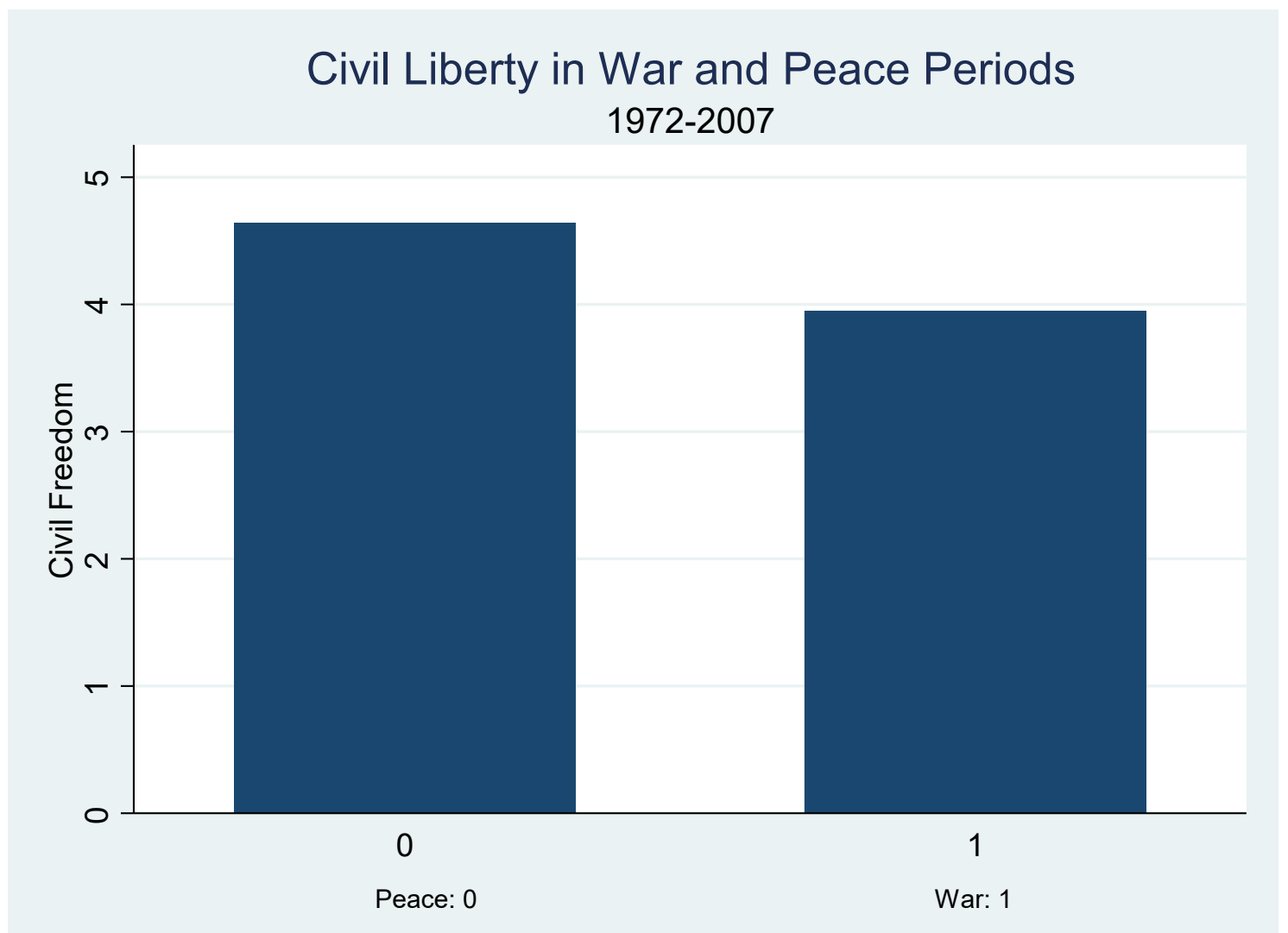

Furthermore, the government and politicians may limit civil liberty by justifying a war as a just war. For example, the U.S. political leaders justified controlling civil freedom by arguing the U.S. is fighting against enemy states that harm racial equality in World War II (Tushnet 2003, 278). Public liberty ensures terrorists' freedom to conduct terrorism activities (Eyerman 1998, 154; Ross 1993, 322). 
Literature that explores relationships between freedom and terrorism were divided into the two arguments. The first one argued that more liberty results in fewer terrorist activities (Kurrild-Klitgaard, Justesen, and Klemmensen 2006, 290). If participation in democratic politics costs less than conducting terrorist activities, terrorist groups will lose an incentive to participate in terrorist activities (Kurrild-Klitgaard, Justesen, and Klemmensen 2006, 296). Citizens have "a peaceful opportunity to try to change the political status quo by criticizing the holders of power and have an open discussion of political means and aims" (Eskildsen, Skjoldager, and Bjørnskov 2020, 4). In terms of a non-democratic regime, because a certain level of freedom of expression and media help leaders to have information about potential threats, strong controlling liberty in expression help terrorist groups to keep their insurgent activities secret (Egorov, Guriev, and Sonin 2009, 647).

The second argument is that freedom and counterterrorism are in conflict with each other. Terrorist groups can organize terrorist activities at a lower cost in a liberal society because higher protection of civil freedom prevents a government from controlling terrorists (Crenshaw 1981, 383; Eubank and Weinberg 2006 , 308-309; Schmid 1992). Freedom of expression increases the risk of terrorist attacks by contributing to the recruitment of potential members and spread of fear from terrorism (Eskildsen, Skjoldager, and Bjørnskov 2020, 3-6). Reduction of privacy protection helps counterterrorism groups to foil terrorist attacks (Bell 2011, 4; Dragu 2011, 65). Higher institutional restriction on government's power may increase terrorist attacks by ensuring higher civil freedom and human rights ( $\mathrm{Li}$ 2005, 281). The institutional restriction limits government's power in counterterrorism because "freedom of association, speech and movement may make it easier for terrorists to organize and operate" (Kurrild-Klitgaard, Justesen, and Klemmensen 2006, 293; Lepsius 2004, 435-436).

As civil liberty is limited during wartime, terrorist groups confront severe security inspection from the government. In terms of freedom of press, freedom of press is very instrumental in terrorist incidents because terrorist activities spread fear to broader target groups more easily through media (Wilkinson 1997, 52-53). Freedom of press generates more incentives for terrorist activities. Because war tension severely restrict freedom of expression, terrorist groups lose the motivation for their attack.

H3-1: A country with lower civil liberty during an interstate war period is less likely to suffer from domestic terrorist incidents.

H3-2: A country with lower civil liberty during an interstate war period is less likely to suffer from transnational terrorist incidents. 


\section{METHODOLOGY}

The research mainly relies on a statistic analysis because there are few systematic empirical analyses estimating the effects of interstate wars on terrorism at the monadic level. This paper applies two kinds of empirical analyses: the one is by comparative analysis and the other is a regression analysis. This research compared the annual average number of terrorist incidents in the war period to the non-war period to test the hypotheses. The time range of this research is 38 years, from 1970 to 2007. Sample countries are 47 countries $^{2}$ that had suffered from wars from 1970 to 2007. The total sample size is 1786 .

\section{THE DEPENDENT VARIABLE}

The dependent variable is the annual number of terrorism incidents in each country. This research analyzes terrorism incidents from 1970 to 2007 by using terrorism data of Enders, Sandler, and Gaibulloev (2011). The reason why I used the terrorism data of Enders, Sandler, and Gaibulloev is that Enders, Sandler, and Gaibulloev divided terrorist incidents into domestic and international terrorism incidents by applying four criteria (2011, 323). "Domestic terrorism is homegrown in which the venue, target, and perpetrators are all from the same country. Thus, domestic terrorism has direct consequences for only the venue country, its institutions, citizens, property, and policies" (Enders, Sandler, and Gaibulloev 2011, 321). Aum Shinrikyo's sarin attack on the Tokyo subway in 1995, Timothy McVeigh's bombing on the Alfred P Murrah Federal Building in Oklahoma City in 1995, and the Tamil Tigers' suicide attacks in Sri Lanka are domestic terrorist incidents (Enders, Sandler, and Gaibulloev 2011, 319). Transnational terrorism is a terrorist attack against entities who have different nationalities from the perpetrators, such as foreign citizens, diplomats (diplomatic staff, their families, and property), an international organization or international peacekeepers (Enders, Sandler, and Gaibulloev 2011, 321, 323).

\section{THE INDEPENDENT VARIABLE}

The primary independent variable is interstate wars. This work used the number of interstate wars in given years. A war and international (or transnational) terrorism should be distinguished. The general definition of war is "sustained combat, involving organized armed forces, resulting in a minimum of 1,000 battle-related fatalities" (Sarkees 2010, 1). FBI (Federal Bureau of

\footnotetext{
${ }^{2}$ The list of fourteen seven war countries are in Table 5 in Appendix
} 
Investigation) defined international terrorism as "violent, criminal acts committed by individuals and/or groups who are inspired by, or associated with, designated foreign terrorist organizations or nations (state-sponsored)”. However, this definition just focuses on perpetrators' foreign nationality, so it cannot encompass terrorist attacks against victims who have a foreign nationality. Enders, Sandler, and Gaibulloev (2011) suggested a more suitable and comprehensive definition of transnational terrorism that is, violent and criminal acts against entities who have different nationalities from the perpetrators, such as foreign citizens, diplomats (diplomatic staff, their families, and property), international organizations or international peacekeepers (Enders, Sandler, and Gaibulloev 2011, 321, 323). The main differences between a war and transnational terrorism are the scale and degree of violence. A war generates a greater number of fatalities (more than 1,000 fatalities) than transnational terrorist attacks. The main target of transnational terrorism is a noncombatant, such as civilians or unarmed soldiers, but a war is conducted between organized military groups, such as military troops or militant groups. The data of war is from the Inter-State War Database of the Correlates of War (COW) project (Sarkees and Wayman, 2010).

Another independent variable is civil liberty in wartime. This project expects that lower civil freedom decreases the possibility of terrorist incidents. Freedom House provides data for civil liberty (Freedom House 2021). The index of civil liberty in an original dataset ranges from 1 to 8.1 means the highest freedom, while 8 is the lowest freedom. The index of civil liberty in this project was inverted for convenience ( 8 is the most freedom, while 1 is the least freedom). An interaction term between war and civil freedom was used in order to measure freedom during wartime.

\section{CONTROL VARIABLES}

Control variables consist of economic growth, trade and FDI dependencies, civil war, civil violence, internal population displacement, refugee inflow, country size, and contiguity. There are various reasons for terrorism, such as ethnic, religious, and ideological conflicts, but the most crucial reason for terrorism is poverty ( $\mathrm{Li}$ and Schaub 2004, 236-237; Mirza and Verdier 2008; Gunaratna, Acharya, and Wang 2010, 155). Poverty increases the dissatisfaction of civilians for the current political regime, social system order, and institution; public dissatisfaction could develop into violent actions to overthrow the existing social order. The most severe terrorism regions are in the third world, such as the Middle East, South Asia, and South America. In economically developed societies, people have much less incentive to participate in terrorism because terrorism harms their economic benefits (Shahzad et al 2016, 183). Data for GDP 
growth are from 1970 to 2007 from the World Bank database (World Bank, 2019).

Internal instability, such as civil war and civil violence is a critical control variable because it represents the domestic instability of the sample countries. Because internal disputes fuel terrorist activities in many cases, the civil war period and civil violence should be controlled. The civil war variable indicates how many years a state has suffered from civil war. The civil war data is from the Intra-State War of COW project (Sarkees and Wayman, 2010). Civil violence is "associated acts of violation and destruction, carried out as a sign of defiance against a central authority or between opposing groups of people, can occur in societies which we consider to be 'modern and progressive"' (Gupte 2011). Civil violence data were taken from the Major Episodes of Political Violence (MEPV) dataset by the Center for System Peace (Marshall 2019). The CIVVIOL index in the dataset that measured civil violence ranges from 1 (lowest) to 10 (highest) (Marshall 2019, 4).

Trade and FDI that represent degrees of economic globalization have positive and negative effects on terrorist incidents. The impact of trade on terrorist attacks is controversial. Trade can reduce domestic and transnational terrorist incidents if it boosts the economy ( $\mathrm{Li}$ and Schaub 2004, 230). A state's economic improvement through trade decreases the motivation for domestic terrorism that destroys its economy. Moreover, as trade boosts a country's economy, citizens in the country have little incentive to engage in transnational terrorist attacks against its trade partner ( $\mathrm{Li} \&$ Schaub 2004, 231). In terms of reducing poverty, international trade reduces terrorist activities because it reduces poverty, a primary cause of terrorism (Johnston 2001; Tyson 2001, Bush, 2002). Trading goods and services improves local human capital and markets because international trade lets private corporations develop sustainable environments by investing in local human capital and markets. These practices will gradually eliminate poverty (Fandl 2003, 612). On the other hand, the U.S. government has regarded free trade as a way of preventing terrorist activities in Muslim countries (Looney 2005, 104-105) because free trade can liberalize Muslim countries economically and politically. The US has attempted to form free trade agreements with Muslim countries to boost their economy (Lindsey 2003, 6).

On the contrary, trade also may increase terrorist incidents by lowering cost of illegal activity and networks. Transnational terrorist groups have used international trade, investment, and distribution networks as a route of trading contrabands such as weapons, drugs, and diamonds (Matthew \& Shambaugh, 1998, p.169-170). "As globalization increases, the cost of illegal activity declines relative to the cost of legal activity, and the overall level of terrorism increases. This decreased risk results from the expansion of the trade, financial, and 
production investment networks in the global economy" ( $\mathrm{Li}$ and Schaub 2004, 234). For example, "obviously, a $2 \%$ chance of discovery is much too low to seriously prevent determined terrorist organizations from smuggling weapons of mass destruction across international borders or from conducting profitable illegal trade to finance terrorist operations" (Li and Schaub 2004, 235). Illicit drug trade promotes transnational and domestic terrorist attacks because drug money helps terrorist groups obtain weapons and equipment, recruit more members, bribe officials and establish networks of communications and safe houses (Piazza 2011, 298).

FDI also has similar effects with trade on terrorist attacks. FDI provides more opportunities to conduct illegal exchanges to terrorist groups. "Higher foreign investment may spur economic activities in the host country. Increase in economic development and resulting employment opportunities may increase the opportunity cost of terrorism, which decreases terrorism activities (Shahzad and Hussain, et al 2016, 183)". On the contrary, FDI provides many routes for smuggling illegal products, such as money, drug, and weapon, to aid terrorist groups (Mirza and Verdier 2007). The project applied trade (import and export) per GDP and FDI net inflow per GDP to show how much the national economy depends on trade and FDI net inflow. This data came from the World Bank database (World Bank, 2019).

Demographic variations that influence terrorist attacks should be controlled, such as internal displaced population and refugee inflow. 'Forcibly Displaced Populations 1964-2008' dataset by the Center for Systemic Peace provides data for numbers of internally displaced people (IDPxx) and refugee inflow (SOURCExx). The scales in the two indexes are 1,000 (Marshall 2008, 1).

Geographical conditions are important factors in conducting terrorist activities because a geographical advantage, such as contiguity helps terrorist groups conduct terrorist activities in foreign countries (Shelley 2006, 258). If a certain country is geographically close with many other countries, it may face more threats from terrorist activities than a state that is geographically isolated (De Sousa, Mirza, and Verdier 2009, 456). This project applied Direct Contiguity (v3.2) from the Correlates of War project that provides the aggregate number of direct contiguities (land and sea) for each country (Hensel 2017, 3). Country size should be controlled for because bigger countries suffer from more terrorist incidents than smaller states. For example, terrorism data shows that Russia, the largest country, had suffered 1744 terrorist incidents from 1991 to 2010; Ukraine had suffered just 42 terrorist incidents during the same period (National Consortium for the Study of Terrorism and Responses to Terrorism). Population reflects country size. A larger population state suffered from more terrorist 
incidents than a state that had a smaller population because it is hard to monitor the larger population, and the composition of a population is more diverse (Eyerman 1998, 160; Li and Schaub 2004, 241). Population data were taken from the World Bank data (World Bank, 2009).

\section{RESULT}

Graph 3: the Impact of Interstate Wars on Domestic Terrorist Incidents

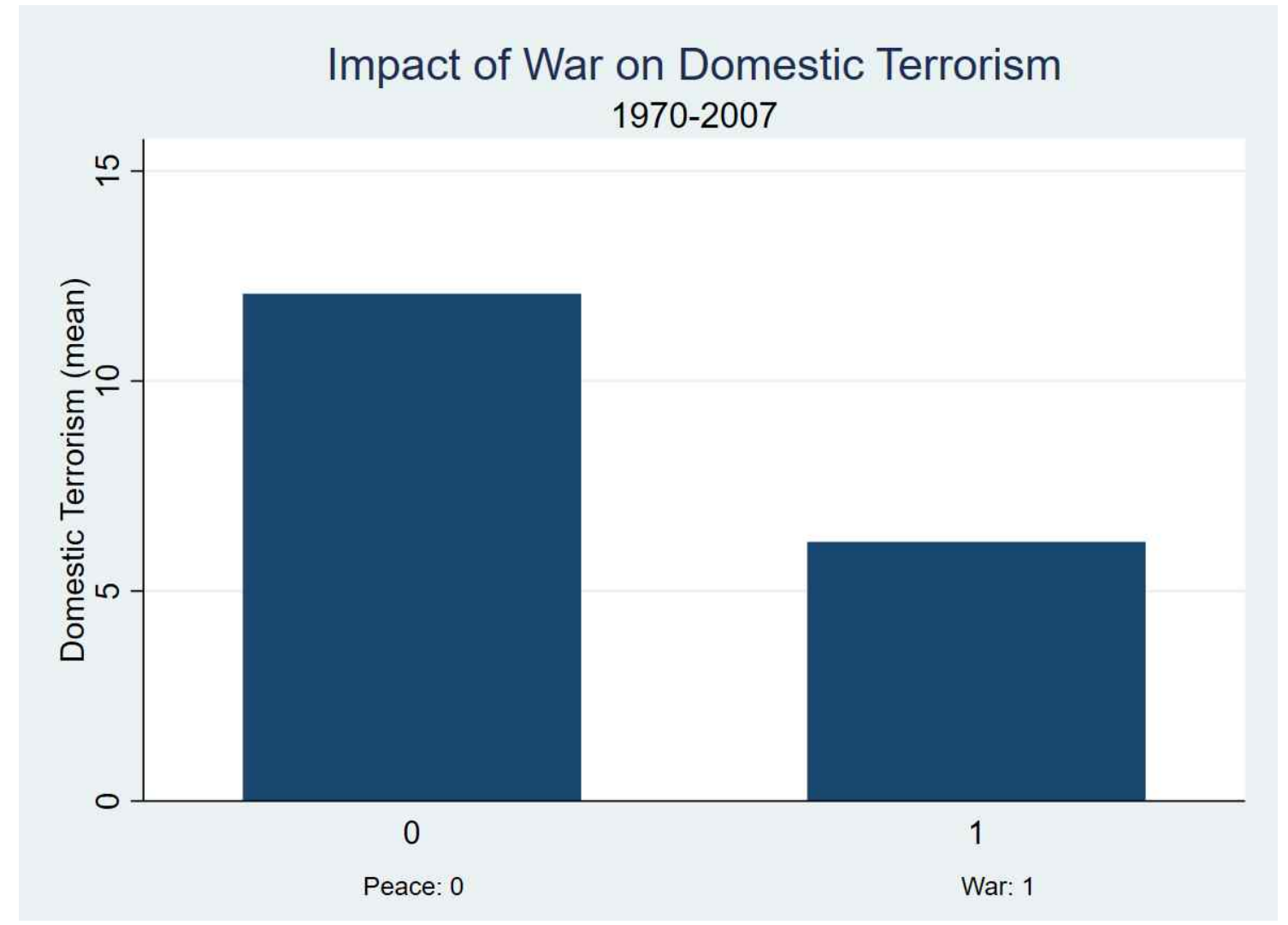

The $\mathrm{x}$-coordinate in Graph 3 indicates a war year. According to the dummy of the war year, 0 indicates no war in given years, while 1 indicates war years. Graph 3 showed the average number of domestic terrorist incidents in war periods was 6.16, while the average number of domestic terrorist incidents in the non-war periods was 12.07. During wartime, countries suffered about 49 percent less domestic terrorism incidents than during the non-war periods. The result means that interstate wars have an impact in reducing terrorism and supports the first hypothesis. These results demonstrate effects of the diversionary war and the 
control of freedom during wartime. Because wars diverted public dissatisfaction on existing problems and limited civilians' fundamental liberty, terrorist groups' motives decreased.

Graph 4: the Impact of Interstate Wars on Transnational Terrorist Incidents

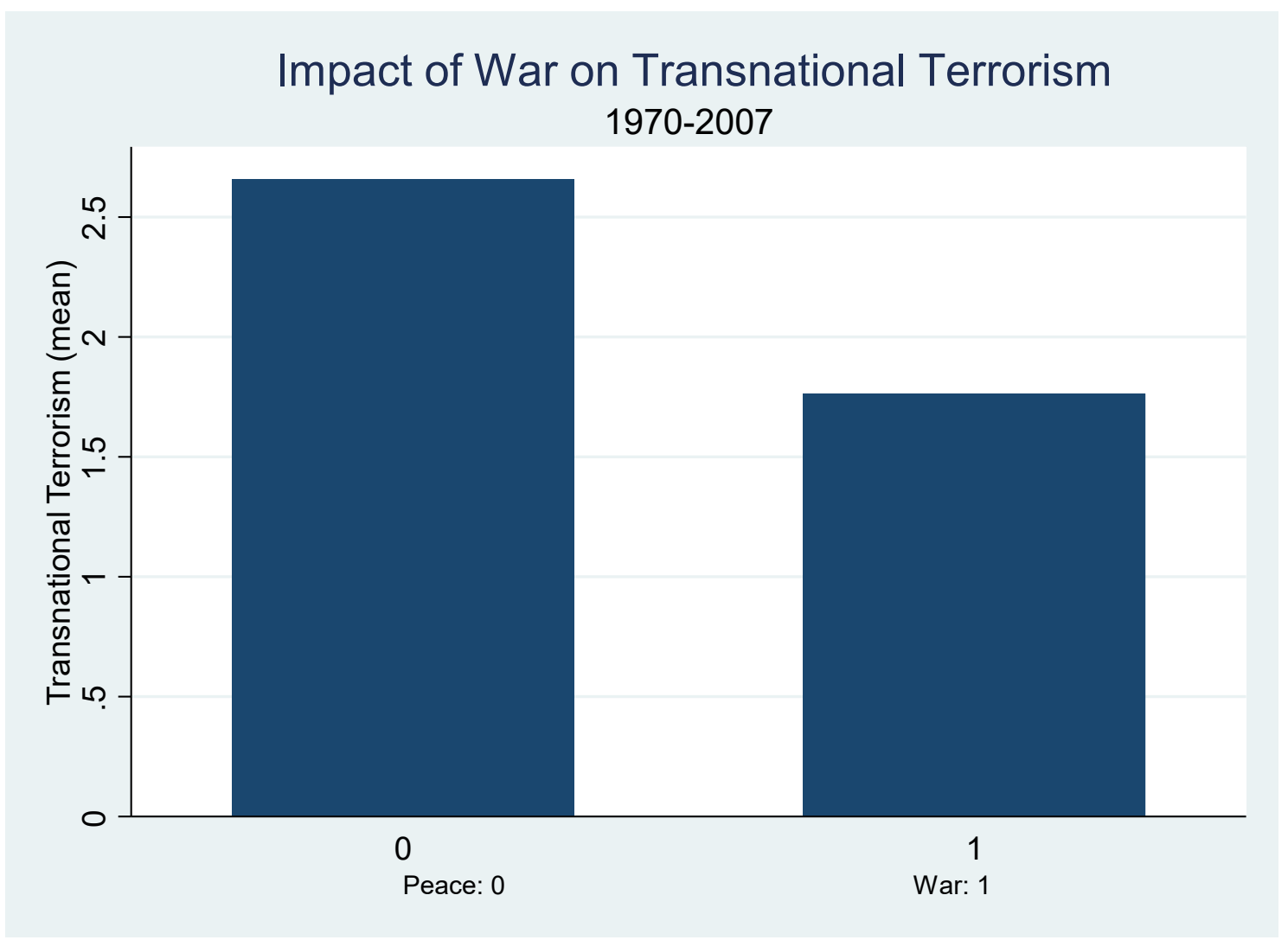

According to Graph 4, the average number of transnational terrorist incidents in wartime was 1.76, while the average number of transnational terrorist incidents in the non-war periods was 2.65. During wartime, countries suffered about 34 percent less transnational terrorist incidents than during the non-war periods. Because transnational terrorist incidents decreased significantly during the war periods, Graph 4 proved the second hypothesis. Because wars limited trade between countries, transnational terrorist groups lost routes to transfer sources for terrorist activities, such as weapons, drugs, and funds.

By comparing domestic and transnational terrorist incidents, wars reduced 49 percent domestic terrorist incidents, while 34 percent transnational terrorist incidents decreased. Domestic terrorist incidents were more significantly impacted from wars than transnational terrorist incidents. The results 
demonstrate that the diversion effect of wars is more significant than the trade restriction effect of realism during wars.

Table 1: the Result of Domestic Terrorist Incident

\begin{tabular}{|c|c|c|}
\hline & Model I & Model II \\
\hline war & $\begin{array}{c}-0.5371 * \\
(0.2830) \\
\end{array}$ & $\begin{array}{c}-0.5371 * * \\
(0.2212) \\
\end{array}$ \\
\hline civil liberty & $\begin{array}{c}0.1965 * * * * \\
(0.0447) \\
\end{array}$ & $\begin{array}{c}0.1965 * * * \\
(0.0588)\end{array}$ \\
\hline civil war & $\begin{array}{c}0.1724 * * * * \\
(0.0473) \\
\end{array}$ & $\begin{array}{c}0.1724 * * * \\
(0.0553)\end{array}$ \\
\hline civil violence & $\begin{array}{c}0.8409 * * * \\
(0.1375)\end{array}$ & $\begin{array}{c}0.8409 * * * \\
(0.1010)\end{array}$ \\
\hline GDP growth & $\begin{array}{c}0.0066 \\
(0.0103)\end{array}$ & $\begin{array}{c}0.0066 \\
(0.0120)\end{array}$ \\
\hline FDI/GDP & $\begin{array}{c}-0.1089 * * * \\
(0.0226)\end{array}$ & $\begin{array}{c}-0.1089 * * * \\
(0.0259)\end{array}$ \\
\hline trade/GDP & $\begin{array}{c}-0.0016 \\
(0.0024) \\
\end{array}$ & $\begin{array}{l}-0.0016 \\
(0.0043) \\
\end{array}$ \\
\hline population & $\begin{array}{c}1.16 \mathrm{e}-09 * * * \\
(3.77 \mathrm{e}-10)\end{array}$ & $\begin{array}{c}1.16 \mathrm{e}-09 * * * \\
(3.42 \mathrm{e}-10)\end{array}$ \\
\hline population displacement & $\begin{array}{c}0.0011 * * * * \\
(0.0002)\end{array}$ & $\begin{array}{c}0.0011 * * * \\
(0.0002)\end{array}$ \\
\hline refugee & $\begin{array}{c}0.0007 * * * * \\
(0.0002)\end{array}$ & $\begin{array}{c}0.0007 * * * \\
(0.0002)\end{array}$ \\
\hline contiguity & $\begin{array}{c}0.0843 * * * \\
(0.0221) \\
\end{array}$ & $\begin{array}{c}0.0843 * * * \\
(0.0252) \\
\end{array}$ \\
\hline constant & $\begin{array}{c}0.3210 \\
(0.3911) \\
\end{array}$ & $\begin{array}{c}0.3210 \\
(0.5499) \\
\end{array}$ \\
\hline observation & 1,081 & 1,081 \\
\hline
\end{tabular}

$\mathrm{P}<0.1: *, \mathrm{P}<0.05: * *, \mathrm{P}<0.01: * * *$

Table 1 reports empirical results for the number of domestic terrorist incidents in a given year. Model I was a negative binomial regression model, and Model II was a negative binomial regression model with a robustness test. Both models show similar results. Interstate wars have negative significant relationships with domestic terrorist incidents in both models. In wartime, states have suffered from less domestic terrorism than in a non-wartime. Endogenous conflicts, such as ethnic, religious, class, and racial conflicts could be stabilized during a war because external conflicts divert citizens' discontent for these problems (Coser, 1956). For instance, Iraq's Saddam Hussein regime enjoyed the diversionary strategy in order to divert citizens' attention on economic and political problems 
in the 1980s-1990s. Iraq had fought against Middle Eastern countries, Israel, and the U.S., such as the Iran-Iraq War and the Gulf War (Kanat 2014, 23). During the wars, on average less than one domestic terrorist incident (0.82) per year occurred. Moreover, as a state has controlled civil freedom in a war to prevent espionage and sabotage, terrorists' activities could be limited (Li 2005, 282; Stone 2003, 223). These statistical results support the first hypothesis. Civil freedom has a meaningful impact on domestic terrorist activities. Higher civil liberty significantly increased domestic terrorist attacks because controlling liberty can limit terrorist activities by increasing the cost of terrorist activities.

In terms of control variables, a civil war has a positive significant relationship with domestic terrorism. Longer civil wars increased domestic terrorist incidents because both depend on existing domestic conflicts, such as religious, ethnic, class, and racial conflicts. Domestic terrorism is a means of those conflicts, and the civil war is the maximum violence that the domestic conflicts cause. A rebel group terrorizes citizens in order to eliminate and deter their cooperation with a government during a civil war period (Walter, 1969). For example, the Shining Path, the Peruvian rebel group, terrorized the Peruvian government and civilians during a civil war in the 1980s and 1990s (Findley and Young 2012, 285). Civil violence also had positive significant relationships with domestic terrorism. Civil violence is a result of conflicts and instability that triggers terrorist incidents. Terrorist groups enjoy social instability and conflicts to formulate an atmosphere of legitimizing terrorist activities.

In terms of economic development, the GDP growth rate did not have statistically significant relationships with domestic terrorism. Economic development did not influence domestic terrorism significantly. Economic globalization influenced domestic terrorism. The ratio of FDI to GDP also showed negative significant relations with domestic terrorist incidents. A state that heavily depends on FDI suffered fewer domestic terrorist incidents. "Higher foreign investment may spur economic activities in the host country. An increase in economic development and resulting employment opportunities may increase opportunity cost of terrorism, which decreases terrorism activities" (Shahzad et al 2016, 183). However, trade dependency did not affect domestic terrorism. Trade dependency had negative relationships with domestic terrorism, but they were not statistically significant.

Country size and borders had positive significant relationships with domestic terrorist incidents. Bigger countries suffered from more domestic terrorist events than smaller states because the composition of the population is more heterogeneous, and it is difficult to police a larger population (Eyerman 1998, 160; Li and Schaub 2004, 241). Population movements increased terrorist incidents. 
Internally displaced population and refugee inflow had meaningful impacts on domestic terrorist attacks. The demographic changes may cause disputes between refugees and local people in terms of a shortage of resources, such as lands, foods, waters, and jobs (Ibáñez and Vélez 2008, 661).

Countries that share borders with many other countries had domestic terrorism than geographically isolated states because borders provided many opportunities for crossing criminals, terrorists, and illicit commodities (Shelley 2006, 257-258).

Table 2: the Result of Domestic Terrorist Incident (civil liberty)

\begin{tabular}{|c|c|c|}
\hline & Model I & Model II \\
\hline $\begin{array}{l}\text { civil liberty } \\
\text { (interaction) }\end{array}$ & $\begin{array}{l}-0.0633 \\
(0.0509)\end{array}$ & $\begin{array}{c}-0.0633 * \\
(0.0376)\end{array}$ \\
\hline civil liberty & $\begin{array}{c}0.2023 * * * \\
(0.0451)\end{array}$ & $\begin{array}{c}0.2023 * * * \\
(0.0598)\end{array}$ \\
\hline civil war & $\begin{array}{c}0.1700 * * * \\
(0.0472)\end{array}$ & $\begin{array}{c}0.1700 * * * \\
(0.0558)\end{array}$ \\
\hline civil violence & $\begin{array}{c}0.8516 * * * \\
(0.1378)\end{array}$ & $\begin{array}{c}0.8516 * * * \\
(0.1018)\end{array}$ \\
\hline GDP growth & $\begin{array}{c}0.0081 \\
(0.0104)\end{array}$ & $\begin{array}{c}0.0081 \\
(0.0123)\end{array}$ \\
\hline FDI/GDP & $\begin{array}{c}-0.1081 * * * \\
(0.0226)\end{array}$ & $\begin{array}{c}-0.1081 * * * \\
(0.0258)\end{array}$ \\
\hline trade/GDP & $\begin{array}{l}-0.0015 \\
(0.0024)\end{array}$ & $\begin{array}{l}-0.0015 \\
(0.0043)\end{array}$ \\
\hline population & $\begin{array}{c}1.17 \mathrm{e}-09 * * * \\
(3.77 \mathrm{e}-10)\end{array}$ & $\begin{array}{c}1.17 \mathrm{e}-09 * * * \\
(3.44 \mathrm{e}-10)\end{array}$ \\
\hline population displacement & $\begin{array}{c}0.0011 * * * \\
(0.0002)\end{array}$ & $\begin{array}{c}0.0011 * * * \\
(0.0002)\end{array}$ \\
\hline refugee & $\begin{array}{c}0.0007 * * * \\
(0.0002)\end{array}$ & $\begin{array}{c}0.0007 * * * \\
(0.0002)\end{array}$ \\
\hline contiguity & $\begin{array}{c}0.0830 * * * \\
(0.0220) \\
\end{array}$ & $\begin{array}{c}0.0830 * * * \\
(0.0254)\end{array}$ \\
\hline constant & $\begin{array}{c}0.2752 \\
(0.3910)\end{array}$ & $\begin{array}{c}0.2752 \\
(0.5534)\end{array}$ \\
\hline observation & 1,081 & 1,081 \\
\hline
\end{tabular}

$\mathrm{P}<0.1: *, \mathrm{P}<0.05: * *, \mathrm{P}<0.01: * * *$

Table 2 revealed statistical results for the relationship between freedom in wartime and domestic terrorist incidents. Model I is a negative binomial regression model, and Model II is a negative binomial regression model with a robustness test. Interaction terms for war and civil liberty had negative relationships with domestic terrorist incidents. Model II showed a statistically significant 
relationship. Lower freedom during war increases domestic terrorism. This result was opposite to the expectation. As controlling civil liberty during a war increases antipathy toward a government, citizens have the motivation to participate in terrorist activities. This result did not support the hypothesis $3-1$. However, civil freedom increased domestic terrorist activities. Empirical results reported positive significant relationships. Because counterterrorism limits public liberty, a society that ensures civil freedom could not control terrorist activities effectively (Bell 2011, 4; Dragu 2011, 65).

The duration of the civil war also had positive significant relationships with domestic terrorist incidents. A longer civil war increased domestic terrorist attacks than a shorter civil war. Because terrorism was a tool that insurgent troops use in order to prevent civilians from cooperating with a government troop in a civil war, domestic terrorism during the civil war increased (Walter, 1969). Civil violence also had a similar effect on domestic terrorist incidents. A state that had a greater number of civil violence suffered from more domestic terrorist attacks than a stable country. This result verified that conflicts may escalate into terrorism.

Economic development (GDP growth) had positive relationships with domestic terrorist incidents, but they were not statistically significant. Fast economic development did not bring about political violence. In terms of economic globalization, the ratio of trade to GDP and FDI per GDP had negative relationships with a domestic terrorist incident. Trade dependency was not statistically significant. Dependencies in trade did not have a substantial effect on a domestic terrorist incident. However, FDI dependency had a meaningful effect on the decrease of domestic terrorist incidents. A country that relies on FDI suffers from less domestic terrorist activities than a state with lower FDI dependency.

Demographic variation had a meaningful impact on domestic terrorist incidents. More force displaced people and refugee inflow promoted more domestic terrorist activities. Significant population movements cause local conflicts between migrants and local population because they have to share limited local resources, such as foods, houses, and jobs (Ibáñez and Vélez 2008, 661).

Geographical conditions, such as country size and the number of borders had positive significant relationships with a domestic terrorist incident. These results reflected that a state that has a larger population and more borders suffer a greater number of domestic terrorist incidents (Eyerman 1998, 160; Li and Schaub 2004, 241). 
Table 3: the Result of Transnational Terrorist Incident

\begin{tabular}{|c|c|c|}
\hline & Model I & Model II \\
\hline war & $\begin{array}{c}-0.5623 * * \\
(0.2496) \\
\end{array}$ & $\begin{array}{c}-0.5623 * * * \\
(0.2085) \\
\end{array}$ \\
\hline civil liberty & $\begin{array}{c}0.1268 * * * \\
(0.0340) \\
\end{array}$ & $\begin{array}{c}0.1268 * * * * \\
(0.0424) \\
\end{array}$ \\
\hline civil war & $\begin{array}{c}0.0536 \\
(0.0407) \\
\end{array}$ & $\begin{array}{c}0.0536 \\
(0.0510) \\
\end{array}$ \\
\hline civil violence & $\begin{array}{c}0.4315 * * * \\
(0.1164)\end{array}$ & $\begin{array}{c}0.4315 * * * \\
(0.0941)\end{array}$ \\
\hline GDP growth & $\begin{array}{c}0.0113 \\
(0.0070)\end{array}$ & $\begin{array}{c}0.0113 \\
(0.0126)\end{array}$ \\
\hline FDI/GDP & $\begin{array}{c}-0.1450 * * * \\
(0.0239)\end{array}$ & $\begin{array}{c}-0.1450 * * * \\
(0.0319)\end{array}$ \\
\hline trade/GDP & $\begin{array}{c}-0.0039 * \\
(0.0023)\end{array}$ & $\begin{array}{l}-0.0039 \\
(0.0031)\end{array}$ \\
\hline population & $\begin{array}{l}-1.49 \mathrm{e}-10 \\
(2.96 \mathrm{e}-10)\end{array}$ & $\begin{array}{l}-1.49 \mathrm{e}-10 \\
(3.07 \mathrm{e}-10)\end{array}$ \\
\hline population displacement & $\begin{array}{c}0.0006 * * * * \\
(0.0002)\end{array}$ & $\begin{array}{l}0.0006 * * \\
(0.0003) \\
\end{array}$ \\
\hline refugee & $\begin{array}{c}0.0003 * * * \\
(0.0001)\end{array}$ & $\begin{array}{c}0.0003 * * * \\
(0.0001)\end{array}$ \\
\hline contiguity & $\begin{array}{c}0.0886 * * * \\
(0.0168) \\
\end{array}$ & $\begin{array}{c}0.0886 * * * \\
(0.0193) \\
\end{array}$ \\
\hline constant & $\begin{array}{l}-0.0972 \\
(0.3000)\end{array}$ & $\begin{array}{l}-0.0972 \\
(0.4005)\end{array}$ \\
\hline observation & 1,081 & 1,081 \\
\hline
\end{tabular}

$\mathrm{P}<0.1: *, \mathrm{P}<0.05: * *, \mathrm{P}<0.01: * * *$

Table 3 shows the results for transnational terrorism. Model I was a negative binomial regression model. Model II was a negative binomial regression model with a robust option. Both models revealed quite similar results that wars had negative significant relationships with transnational terrorism. Because wars limited civil liberty, trade, and foreign investment, transnational terrorist groups had smaller incentives and sources for terrorism activities (Fandl 2003, 612; Shahzad et al 2016, 183; Tushnet 2003, 274). These statistical results support the second hypothesis. Civil freedom had a meaningful impact on international terrorist incidents. Greater liberty increased the number of transnational terrorist incidents. This result demonstrates that more civil freedom may give more opportunities to conduct terrorist activities toward transnational terrorist groups.

Civil wars did not show a meaningful impact on transnational terrorism. An intra war did not promote transnational terrorist groups' activities. However, civil 
violence had positive significant relationships with transnational terrorist incidents. Civil violent disputes provide room to intervene for transnational terrorists because social instability can weaken national security (Addison and Murshed 2005, 13).

Economic development had no significant relationship with transnational terrorist incidents. Fast economic growth did not influence transnational terrorist incidents. Economic globalization factors, such as trade and FDI dependencies, had negative significant relationships with transnational terrorism. A country that highly relies on trade and FDI prefers to maintain stability over an isolated economy by preventing transnational terrorist incidents because terrorism damages its economy by limiting trade (Bush, 2002; Fandl 2003, 612-613; Johnston, 2001; Tyson, 2001). Foreign trade partners are afraid of transnational terrorist groups' attacks against their host country because terrorist attacks severely limit their trade by destroying markets, infrastructures, and facilities of production and distribution. Moreover, because FDI that provides various economic benefits, such as employment has a strong anti-terrorism effect, terrorist groups lose motivation for terrorism under a developed economy that relies on FDI (Shahzad et al 2016, 183).

Internal population displacement and refugee inflow showed positive significant relationships with transnational terrorist incidents. Radical demographic changes affect local stability. As many migrants and refugees enter a region, various disputes related to resources, religion, and ethnicity occur. These conflicts can be a motivation of transnational terrorist attacks in order to support one side (Ibáñez and Vélez 2008, 661).

In terms of geographical conditions, country size did not have a significant impact on the number of transnational terrorist incidents, while the number of borders had a positive significant relationship with transnational terrorism (Eyerman 1998, 160; Li and Schaub 2004, 241). A state that has more neighboring countries suffered from more transnational terrorist incidents than a country that has less surrounding countries (De Sousa, Mirza, and Verdier 2009, 456). More borders give more chances of terrorist activities to transnational terrorist groups (Shelley 2006, 257-258). For example, because Pakistan is a neighboring country that shares a border with Afghanistan, Pakistan has suffered from many transnational terrorist attacks from Afghanistan militant groups, such as Taleban and $\mathrm{Al}-$ Qaeda. These groups have transferred huge amount of contrabands, such as weapons and drugs to terrorist groups in Pakistan through the border (Zeb 2006, 69-70). 
Table 4: the Result of Transnational Terrorist Incident (Civil Liberty)

\begin{tabular}{|c|c|c|}
\hline & Model I & Model II \\
\hline $\begin{array}{c}\text { civil liberty } \\
\text { (interaction) }\end{array}$ & $\begin{array}{c}-0.0923 * * \\
(0.0460) \\
\end{array}$ & $\begin{array}{c}-0.0923 * * \\
(0.0405) \\
\end{array}$ \\
\hline civil liberty & $\begin{array}{c}0.1347 * * * \\
(0.0341)\end{array}$ & $\begin{array}{c}0.1347 * * * \\
(0.0422)\end{array}$ \\
\hline civil war & $\begin{array}{c}0.0485 \\
(0.0407)\end{array}$ & $\begin{array}{c}0.0485 \\
(0.0514)\end{array}$ \\
\hline civil violence & $\begin{array}{c}0.4413 * * * \\
(0.1166) \\
\end{array}$ & $\begin{array}{c}0.4413 * * * \\
(0.0950) \\
\end{array}$ \\
\hline GDP growth & $\begin{array}{c}0.0116 * \\
(0.0070) \\
\end{array}$ & $\begin{array}{c}0.0116 \\
(0.0128) \\
\end{array}$ \\
\hline FDI/GDP & $\begin{array}{c}-0.1428 * * * \\
(0.0238)\end{array}$ & $\begin{array}{c}-0.1428 * * * \\
(0.0320)\end{array}$ \\
\hline trade/GDP & $\begin{array}{c}-0.0039 * \\
(0.0023)\end{array}$ & $\begin{array}{l}-0.0039 \\
(0.0031)\end{array}$ \\
\hline population & $\begin{array}{l}-1.34 \mathrm{e}-10 \\
(2.96 \mathrm{e}-10)\end{array}$ & $\begin{array}{l}-1.34 e^{-10} \\
(3.08 \mathrm{e}-10)\end{array}$ \\
\hline population displacement & $\begin{array}{c}0.0007 * * * \\
(0.0002)\end{array}$ & $\begin{array}{l}0.0007 * * \\
(0.0003) \\
\end{array}$ \\
\hline refugee & $\begin{array}{c}0.0003 * * * \\
(0.0001)\end{array}$ & $\begin{array}{c}0.0003 * * * \\
(0.0001) \\
\end{array}$ \\
\hline contiguity & $\begin{array}{c}0.0876 * * * \\
(0.0167) \\
\end{array}$ & $\begin{array}{c}0.0876 * * * \\
(0.0193) \\
\end{array}$ \\
\hline constant & $\begin{array}{l}-0.1425 \\
(0.2988) \\
\end{array}$ & $\begin{array}{l}-0.1424 \\
(0.3982) \\
\end{array}$ \\
\hline observation & 1,081 & 1,081 \\
\hline
\end{tabular}

$\mathrm{P}<0.1: *, \mathrm{P}<0.05: * *, \mathrm{P}<0.01: * * *$

Table 4 analyzes how freedom in a war period affects a transnational terrorist incident. Model I was a negative binomial regression model, and Model II was a negative binomial regression model with a robustness test. The two models showed similar statistical results. An interaction term between war and civil freedom showed negative significant relationships with transnational terrorism. As similar with empirical results for domestic terrorism, lower wartime freedom promoted more transnational terrorist activities. This is unexpected because limitation of civil liberty during wartime may reduce chances to conduct terrorist activities to transnational terrorists. As controlling freedom generates a side effect, public dissatisfaction, transnational terrorist groups have more chances to intervene in disputes between a government and citizens. Hypothesis 3-2 was not supported. On the contrary, civil liberty was positively associated with international terrorist activities. More freedom gives more opportunities to conduct terrorist activities toward transnational terrorists. 
In terms of control variables, a civil war has positive relationships with transnational terrorist incidents, but they were not statistically significant. Civil war did not affect transnational terrorist incidents. However, civil violence increased transnational terrorist attacks significantly. Civil violent conflicts provide many chances to intervene for transnational terrorist groups.

In terms of economic developments, GDP growth had positive significant relationships with transnational terrorist incidents in Model I. Economic growth with higher inequality may promote transnational terrorism because citizens who are dissatisfied with current economic inequality join transnational terrorism. Dependencies of trade and FDI had similar impacts on transnational terrorism. They all have negative significant relationships. This result demonstrates a state that highly relies on trade and FDI tries to keep stability and peace in order to enjoy economic benefits from trade and FDI (Bush, 2002; Fandl 2003, 612-613; Johnston, 2001; Tyson, 2001).

Demographic variation had a meaningful influence on transnational terrorist activities. Greater numbers of internally displaced population and refugees increased transnational terrorist incidents. Larger population movements may destroy social stability by causing diverse disputes between migrants and local population, such as economic, ethnic, and religious conflicts. These disputes can attract transnational terrorists' activities (Braithwaite and Chu 2018, 1641; Ibáñez and Vélez 2008, 661).

Finally, geographical conditions, including country size and contiguity, have different impacts on transnational terrorist incidents. Population did not influence transnational terrorist activities. However, contiguity had positive significant impacts on transnational terrorist activities. A country that has many surrounding states suffers from a greater number of transnational terrorist incidents than a geographically isolated state.

\section{CONCLUSION}

This research examined the relation between interstate wars and terrorism through empirical analyses at the monadic level by applying three theoretical backgrounds, such as the diversionary theory of war, realism, and restriction of freedom. Previous research attempted to conduct only dyadic level analyses rather than monadic level analyses. These theories provided three explanations for how wars reduce terrorism. External military conflicts can reduce domestic terrorist incidents by diverting citizens' discontent. Realists argue that a state is 
reluctant to engage in trade because trade may generate larger benefits to a trade partner that poses an imminent threat. As trade decreases in a war, transnational terrorist groups face higher costs in illegal exchange of contrabands. Liberty limited during a war limits terrorist attacks because terrorist groups confront obstacles of terrorist activities, such as counterterrorism and limitation of freedom of expression.

The empirical analyses found several meaningful points. Interstate wars decreased the number of transnational and domestic terrorism incidents. Moreover, domestic terrorist incidents received a bigger impact from interstate wars than transnational terrorist incidents. According to the diversionary theory of war, an external threat may stabilize domestic conflicts for a while by diverting domestic citizens' attention. A national crisis leads a country to control domestic security more strictly to maintain national security, such as border closures; more strict domestic security inspection prevents international terrorists from conducting terrorism activities by increasing the costs of terrorist activities ( $\mathrm{Li}$ 2005, 287).

Second, limitation of freedom in the wartime does not play a factor to reduce domestic and international terrorist incidents. During a war period, civil liberty can be controlled for national security. This situation may limit terrorists' activities with strengthened security inspections because terrorists lose a motive for terrorism and bear a greater cost of terrorism. However, lower level of civil liberty in wartime increased more domestic and transnational terrorist incidents. Controlling freedom during a war causes a side effect, public discontent, to promote political violence.

Statistical results for the control variables revealed several meaningful points. Civil wars increased the number of domestic terrorist incidents. The impact of civil wars to domestic terrorist incidents is natural because the same social conflicts bring about civil war and domestic terrorist incidents. Moreover, civil war also increased the number of transnational terrorist incidents significantly because weakened domestic security that the civil war makes a society vulnerable. Furthermore, as a domestic rebel group gets support from foreign terrorist groups during the civil war period might provide a chance for intervention. Civil violence creates environments to conduct domestic and transnational terrorist activities because violent disputes between citizens can provide room for terrorist groups to intervene.

In terms of economic globalization, trade and FDI dependencies decreased transnational terrorist incidents. Higher dependencies on trade and FDI reduced the incentive of terrorist activities because less incentive for terrorist activities exists in the economy that enjoys economic benefits from trade, such as human 
and market developments (Bush 2002; Fandl 2003, 612-613; Johnston 2001; Tyson 2001s).

Demographic variation affects domestic and transnational terrorist incidents. Internally displaced population and refugee inflow brought about domestic and transnational terrorist incidents because they cause conflicts between local people and migrants due to a shortage of resources and religious, ethnic, and racial differences (Ibáñez and Vélez 2008, 661).

Finally, geographical conditions, such as the number of borders and country size are important factors for terrorist incidents. According to the statistical results, the number of borders increased domestic and transnational terrorist incidents. Countries that share more borders with foreign countries suffered from more domestic and transnational terrorist incidents than geographically isolated countries because borders provide many chances for crossing to criminals, terrorists, and illicit commodities (Shelley 2006, 257-258). Statistical results demonstrate that the population also increases domestic terrorist incidents. Larger states suffered from more domestic terrorist incidents than smaller states because greater population includes a more diverse population composition and prevents a public authority from monitoring it (Eyerman 1998, 160; Li and Schaub 2004, 241).

\section{APPENDIX}

Table 5: The List of Fourteen Seven War Countries

War Country (1970-2007)

Australia, Angola, Argentina, Armenia, Australia, Azerbaijan, Bosnia and Herzegovina, Cambodia, Canada, Chad, China, Croatia, Cuba, Cyprus, Democratic Republic of the Congo, Ecuador, Egypt, Eritrea, Ethiopia, France, Germany, India, Iran, Iraq, Israel, Italy, Jordan, Kuwait, Libya, Morocco, Netherlands, Oman, Pakistan, Peru, Qatar, Saudi Arabia, Somalia, South Africa, Syria, Tanzania, Thailand, Turkey, Uganda, United Arab Emirates, United Kingdom, United States of America, Vietnam

Source: Interstate War Data from COW Project

\section{REFERENCE}

Acharya, Arabinda, Rohan Gunaratna, and Wang Pengxin. 2010. Ethnic identity and national conflict in China. New York, NY: Palgrave MacMillan.

Aksoy, Deniz. 2014. "Elections and the timing of terrorist attacks." The Journal 
of Politics 76(4), 899-913.

Addison, Tony, and S. Mansoob Murshed. 2005. "Transnational terrorism as a spillover of domestic disputes in other countries." Defence and Peace Economics 16(2), 69-82.

Barbieri, Katherine, and Jack S. Levy. 1999. "Sleeping with the Enemy: The Impact of War on Trade. Journal of Peace Research 36(4), 463-479.

Bell, Colleen. 2011. The freedom of security: Governing Canada in the age of counter-terrorism. Vancouver: UBC Press.

Bessone, Ramón and Genaro Díaz. 1986. Guerra revolucionaria en la Argentina, 1959-1978. Editorial Fraterna.

Bloomberg News. 2001. "It's time to step up the global war on poverty". (December 3). Available at https://www.bloomberg.com (November 30, 2020).

Braithwaite, Alex, and Tiffany S. Chu. 2018. "Civil conflicts abroad, foreign fighters, and terrorism at home.” Journal of Conflict Resolution 62 (8): 1636-1660.

Byman, Daniel, Peter Chalk, Bruce Hoffman, William Rosenau, and David Brannan. 2001. Trends in Outside Support for Insurgent Movements. Santa Monica, CA: Rand Corporation.

Bush, G. W. (2002) The Statement of the U.S. President George W. Bush at International Conference on Financing for Development [Online]. Available at: http://www.un.org/ffd/statements/usaE.htm (accessed March 22, 2012)

Bush, George W. 2002. "The Statement of the U.S. President George W. Bush at International

Conference on Financing for Development." The United Nations (March 22) Accessed at http://www.un.org/ffd/statements/usaE.htm (March 22, 2012).

Caparini, Marina and Otwin Marenin. (eds.). 2007. Borders and security governance: Managing borders in a globalised world. Hamburg, Germany: Lit Verlag.

Caporaso, James A. 1993. 'Global political economy', in Ada W. Finifter ed., Political Science: The State of the Discipline II, Washington DC: The American Political Science Association, 451-481.

Chen, Yi-Ming, Dachrahn Wu, and Cheng-Kuang Wu. 2009. "A game theory approach for the reallocation of security forces against terrorist diversionary attacks." 2009 IEEE International Conference on Intelligence and Security Informatics. IEEE, 89-94.

Chenoweth, Erica. 2009. "War Initiation and Transnational Terrorism: Is There a Causal Connection.” Paper presented at the Annual Meeting of the International Studies Association, New York, USA (February). 
Choo, Su-Ki. 1995. "Ja-yu-min-ju-ju-ui-e-seo Te-reo-ri-sm-ui Bal-seng-gwa Eon-ron-ui Bo-do: Gong-seng-ui Gwan-gye?”, Keon-kuk Dae-hak-kyo Non-mun-jib Yin-mun. Sa-hoe-hak-pyeon 1995 (29), 417-435.

Conrad, Justin. 2011. "Interstate Rivalry and Terrorism: An Unprobed Link." Journal of Conflict Resolution 55(4), 529-555.

Copeland, Dale C. 1996. "Economic interdependence and war: A theory of trade expectations." International security 20(4), 5-41.

Coser, Lewis A. 1956. The Function of Social Conflict. New York: Free Press.

Crenshaw, Martha. 1981. "The causes of terrorism." Comparative politics 13(4), 379-399.

DeRouen, Karl. "Presidents and the Diversionary Use of Force: A Research Note." International Studies Quarterly 44 (2), 317-328.

De Sousa, Jose, Daniel Mirza, and Thierry Verdier. 2009. "Trade and the spillovers of transnational terrorism." Swiss Journal of Economics and Statistics 145(4), 453-461.

Dragu, Tiberiu. 2011. "Is there a trade-off between security and liberty? Executive bias, privacy protections, and terrorism prevention." American Political Science Review 105(1): 64-78.

Egorov, Georgy, Sergei Guriev, and Konstantin Sonin. 2009. Why Resource-Poor Dictators Allow Freer Media: A Theory and Evidence from Panel Data. American Political Science Review 103(4), 645-668.

Enders, Walter, Todd Sandler, and Khusrav Gaibulloev. 2011. "Domestic Versus Transnational Terrorism: Data, Decomposition, and Dynamics.” Journal of Peace Research 48(3), 319-337.

Eskildsen, Lasse Skjoldager, and Christian Bjørnskov. 2020"Does Freedom of Expression Cause Less Terrorism?.”Political Studies, 1-32.

Eubank, William Lee, and Leonard Weinberg. 2006. "Does Democracy Encourage Terrorism?.” In David C. Rapoport ed., Terrorism: The Third or New Left Wave, New York, NY: Routledge, 306-322.

Eyerman, Joe. 1998. "Terrorism and democratic states: Soft targets or accessible systems," International interactions 24(2), 151-170.

Fandl, Kevin. 2003. "Terrorism, Development \& (and) Trade: Winning the War on Terror Without the War," American University International Law Review 19(3), 587-630.

FBI. "Terrorism”, FBI. Accessed at https://www.fbi.gov/investigate/terrorism (March 1, 2021).

Findley, Michael G., James A. Piazza, and Joseph K. Young. 2012. "Games rivals play: Terrorism in international rivalries," The journal of politics 74(1), 235-248. 
Findley, Michael G., and Joseph K. Young. 2012. "Terrorism and civil war: A spatial and temporal approach to a conceptual problem." Perspectives on Politics 10(2), 285-305.

Foster, Dennis M. 2017. "Inter Arma Silent Leges? Democracy, Domestic Terrorism, and Diversion.” Journal of Conflict Resolution 61 (7), 1371-1400.

Freedom House. 2021. "Country and Territory Ratings and Statuses, 1973-2020", Freedom House. Accessed at https://freedomhouse.org/report/freedomworld/2020/leaderless-struggle-democracy (January 28, 2021).

Goertz, Gary, and Paul F. Diehl. 1993. "Enduring rivalries: Theoretical constructs and empirical patterns," International studies quarterly 37(2), 147-171.

Grieco, Joseph. 1990. Cooperation among nations: Europe, America, and non-tariff barriers to trade. Ithaca, NY: Cornell University Press.

Gupte, Jaideep. 2011. "Civil violence: three steps to understanding the 'mindless criminal", MicroCon. Available at https://microconflict.wordpress.com/ 2011/08/10/civil-violence-three-steps-to-understanding-the-mindless-cr iminal/ (March 9, 2021)

Heginbotham, Eric, and Richard J. Samuels. 1998. "Mercantile realism and Japanese foreign policy.” International Security, 22(4), 171-203.

Hensel, Paul. 2017. "Documentation for COW Direct Contiguity Data - Version 3.20 [online]." The Correlates of War. Available at https://correlatesofwar.org/ data-sets/direct-contiguity (May 12, 2019)

Huntington, Samuel. 1993. "Why international primacy matters," International security, 17(4), 68-83

Ibáñez, Ana María, and Carlos Eduardo Vélez. "Civil conflict and forced migration: The micro determinants and welfare losses of displacement in Colombia.” World Development 36.4 (2008): 659-676.

Jai, Kehaulani R. 2016. "Crackdown and consent: China's war on terror and the strategic creation of a public discourse in the US." Scripps Senior Theses 741.

Johnston, Andrew. 2001. "Disparities of wealth are seen as fuel for terrorism," The New York times, (December 20) Available at: https://www.nytimes. com/2001/12/20/news/disparities-of-wealth-are-seen-as-fuel-for-terrorism. html (November 30, 2020)

Kanat, Kilic Bugra. 2012. “War on Terror” as a Diversionary Strategy: Personifying Minorities as Terrorists in the People's Republic of China." Journal of Muslim Minority Affairs 32(4), 507-527.

Kanat, Kilic B. 2014. "Diversionary foreign policy in authoritarian states: the use of multiple diversionary strategies by Saddam Hussein during the Gulf War.” Journal of Strategic Security 7(1), 16-32. 
Kunkel, John. 1998. "Realism and postwar US trade policy.", Pacific Economic Paper. 285, 1-39.

Klein, Graig. 2015. "Political Predators: Transnational Terrorists' Strategic Target Selection as a Mechanism for Political Mobilization.” International Studies Association Annual Conference, New Orleans, Louisiana.

Kurrild-Klitgaard, Peter, Mogens K. Justesen, and Robert Klemmensen. 2006. "The political economy of freedom, democracy and transnational terrorism." Public Choice 128(1-2), 289-315.

Kydd, Andrew H., and Barbara F. Walter. 2006. "The strategies of terrorism," International security, 31(1), 49-80.

Lepsius, Oliver. 2004. "Liberty, security, and terrorism: The legal position in Germany." German Law Journal 5(5), 435-460.

Levy, Jack. 1989. "The Diversionary Theory of War: A Critique" In Manus Midlarsky ed. Handbook of war studies. Ann Arbor, MI: University of Michigan Press, 259-288.

Li, Quan. 2005. "Does Democracy Promote or Reduce Transnational Terrorist Incidents?," Journal of Conflict Resolution 49(2), 278-297.

Li, Quan, and Drew Schaub. 2004. "Economic Globalization and Transnational Terrorism: A Pooled Time-Series Analysis," Journal of Conflict Resolution 48(2), 230-258.

Marshall, Monty G. 2019. "Major Episodes of Political Violence (MEPV) and Conflict Regions, 1946-2018." Center for Systemic Peace.

Marshall, Monty G. 2008. “Forcibly displaced populations, 1964-2008." Center for Systemic Peace.

Matthew, Richard A., and George E. Shambaugh. 1998. "Sex, Drugs, and Heavy Metal: Transnational Threats and National Vulnerabilities," Security Dialogue 29(2), 163-175.

Midlarsky, Manus ed. 1993. Handbook of war studies. Ann Arbor, MI: University of Michigan Press.

Migdalovitz, Carol. 2001. Armenia-Azerbaijan Conflict. Washington D.C.: Library of Congress.

Verdier, Thierry, and Daniel Mirza. 2007. "International Trade, Security and Transnational Terrorism: Theory and Empirics." London: Centre for Economic Policy Research.

Mirza, Daniel and Thierry Verdier. 2008. "International trade, security and transnational terrorism: Theory and a survey of empirics," Journal of comparative economics, 36(2), 179-194.

Napoleoni, Loretta. 2003. Modern jihad: Tracing the dollars behind the terror networks. London, England: Pluto Press. 
National Consortium for the Study of Terrorism and Responses to Terrorism. "Global Terrorism Database," The University of Maryland. Available at: http://www.start-dev.umd.edu/gtd/ (January 21, 2020)

Ndumbe, J. Anyu, and Babalola Cole. 2005. "The illicit Diamond trade, civil conflicts, and terrorism in Africa," Mediterranean quarterly 16(2), 52-65.

Newman, Lindsay Shorr. 2013. "Do terrorist attacks increase closer to elections?." Terrorism and Political Violence 25(1), 8-28.

O'brien, Sean. 1996. "Foreign Policy Crises and the Resort to Terrorism: A Time-Series Analysis of Conflict Linkages," Journal of Conflict Resolution 40(2), 320-335.

Olson, Mancur. 1963. "Rapid growth as a destabilizing force," The Journal of Economic History, 23(4), 529-552.

Piazza, James. 2011. "The illicit drug trade, counternarcotics strategies and terrorism," Public choice, 149(3-4), 297-314.

Pluchinsky, Dennis A. 1998. "Terrorism in the former Soviet Union: A primer, a puzzle, a prognosis," Studies in conflict and terrorism 21(2), 119-147.

Robben, Antonius. 2012. "From dirty war to genocide: Argentina's resistance to national reconciliation." Memory Studies 5(3), 305-315.

Ross, Jeffrey. 1993 "Structural Causes of Oppositional Political Terrorism: Towards a Causal Model.” Journal of Peace Research 30(3), 317-329.

Sarkees, Reid, and Frank Wayman. 2010. Resort to War: 1816-2007. Washington DC: CQ Press.

Sarkees, Meredith Reid. 2010. "The COW typology of war: Defining and categorizing wars (version 4 of the data)." Note with version 4 of the Correlates of War Data.

Schmid, Alex. 1992. Terrorism and democracy. Terrorism and Political Violence, 4(4), 14-25.

Shahzad, Hussain, Muhammad Zakaria, Mobeen Rehman, Tanveer Ahmed, and Bashir Fida. 2016. "Relationship between FDI, Terrorism and Economic Growth in Pakistan: Pre and post 9/11 Analysis," Social Indicators Research 127(1), 179-194.

Shelley, Louise . 2006. "Border Issues: Transnational Crime and Terrorism" In Caparini, Marina and Otwin Marenin ed. Borders and Security Governance Managing Borders in a Globalised World. Piscataway, NJ: Transaction Publishers, pp. 255-269.

Sick, Gary. 2003. “Iran: Confronting Terrorism.” Washington Quarterly 26(4), 83-98.

Stone, Geoffrey. 2003. "Civil Liberties in Wartime," Journal of Supreme Court history, 28(3), 215-251. 
Strange, Susan. 1987. "The persistent myth of lost hegemony." International organization, $551-574$.

Suarez-Orozco, Marcelo. 1991. "The heritage of enduring a "dirty war": Psychosocial aspects of terror in Argentina, 1976-1988." The Journal of Psychohistory 18(4), 469-505.

Tir, Jaroslav and Michael Jasinski. 2008. "Domestic-level diversionary theory of war: Targeting ethnic minorities," The journal of conflict resolution, 52(5), 641-664.

Tushnet, Mark. 2003. "Defending korematsu?: Reflections on civil liberties in wartime," Wisconsin Law Review. 2003, 273-307.

Tyson, Laura. 2001 "It's Time to Step up the Global War on Poverty", Business Week. (December 3). Available at: https://www.bloomberg.com/news/ articles/2001-12-02/its-time-to-step-up-the-global-war-on-poverty (June 15, 2019)

Walter, Eugene Victor. 1969. Terror and Resistance: A Study of Political Violence, with Case Studies of Some Primitive African Communities. New York, NY: Oxford University Press.

Waltz, Kenneth. 1979. Theory of international politics. Reading, MA : AddisonWesley.

Whitehead, John W., and Steven H. Aden. 2001. "Forfeiting enduring freedom for homeland security: A constitutional analysis of the USA Patriot Act and the Justice Department's anti-terrorism initiatives." American University Law Review. 51(6), 1083-1133.

Wilkinson, Paul. 1997. "The media and terrorism: A reassessment," Terrorism and political violence, 9(2), 51-64.

World Bank. "World Development Indicators". Available at: https://databank. worldbank.org/source/world-development-indicators (July 22, 2019)

Volpe, Lauren. 2010. Terrifying environments, environing terrorism: An ecofeminist critique of the FBI's response to the Earth Liberation Front. Master Thesis, Texas Woman's University.

Zeb, Rizwan. 2006. "Cross Border Terrorism Issues Plaguing Pakistan-Afghanistan Relations.” China and Eurasia Forum Quarterly. 4 (2), 69-74.

[Received Jan 31, 2021; Revised Mar 16, 2021; Accepted Mar 25, 2021] 